\title{
Study on the Susceptibility of Lncrna PCAT1 Snps and Breast Cancer Risk in the Chinese Population
}

\author{
Linping Xu \\ Henan Provincial Tumor Hospital: Henan Cancer Hospital \\ Yanli Wang \\ Zhengzhou University \\ Ziang Shi \\ Zhengzhou University \\ JianPing Long \\ : Maternity and Children Hospital \\ Qiuyu Sun \\ Zhengzhou University \\ Xiaoru Jiang \\ Zhengzhou University \\ Kedi Xu \\ Zhengzhou University \\ Yuanlin Zou \\ Zhengzhou University \\ Kaijuan Wang \\ Zhengzhou University \\ Chunhua Song ( $\square$ sch16@zzu.edu.cn) \\ Zhengzhou University https://orcid.org/0000-0001-6028-5923
}

\section{Research Article}

Keywords: Breast cancer, IncRNA PCAT1, SNPs, susceptibility

Posted Date: August 9th, 2021

DOl: https://doi.org/10.21203/rs.3.rs-707593/v1

License: () (i) This work is licensed under a Creative Commons Attribution 4.0 International License. Read Full License 


\section{Abstract}

The purpose of this study is to explore the relationship between PCAT1-SNPs and breast cancer (BC) susceptibility. Logistic regression analysis was applied to determine the association between PCAT1-SNPs and BC risk. The relative expression of PCAT1 in different genotypes was detected by qRT-PCR. The binding between the genotype of C/T at rs4473999 locus and miR-149-5p was confirmed by dual luciferase gene reporter assays. The proliferation, migration and invasion of BC cells with dysregulated expression of miR-149-5p was evaluated by CCK8, Scratch and Transwell assay, respectively. Logistic regression analysis revealed PCAT1-SNPs was related to the susceptibility of BC that rs 117117537 (OR:2.413, 95\%Cl: 1.057-5.508) and rs4473999 (OR:2.137 95\%Cl: 1.065-4.286) were risk factors of $\mathrm{BC}$ when the menopausal age was $\geq 50$; The haplotype

$\mathrm{G}_{\mathrm{rs} 1551514} \mathrm{~T}_{\mathrm{rs} 1551513} \mathrm{C}_{\mathrm{rs} 4473999} \mathrm{C}_{\mathrm{rs} 9656964} \mathrm{~T}_{\mathrm{rs} 17762938} \mathrm{C}_{\mathrm{rs} 7823297} \mathrm{~T}_{\mathrm{rs} 785003} \mathrm{~T}_{\mathrm{rs} 117117537}$ may increase the risk of BC (OR:1.614 95\%Cl: 1.1162.333), and there was an association between genes and reproductive factors (OR:2.487 95\%Cl: 1.929-3.206). Preliminary functional studies demonstrated that PCAT1 interacted with miR-149-5p when rs4473999 carried wild type C; In addition, the dysregulated enrichment of miR-149-5p may affect the proliferation, invasion and migration of BC cells. Our study shows that PCAT1 gene polymorphism is related to BC susceptibility, PCAT1-rs4473999 C/T genotype may affect the occurence of BC by modulating the interactions with miR-149-5p.

\section{Introduction}

According to the World Health Organization (WHO) estimates in 2015, cancer is expected to be the leading cause of death worldwide in the 21 st century ${ }^{[1]}$. Worldwide, both the incidence and mortality of breast cancer (BC) were ranked as No.1 in all female-related cancers ${ }^{[2]}$; to make the situation worse, existing epidemiological data showed the incidence of $\mathrm{BC}$ has been increasing steadily in most countries, including China ${ }^{[3,4]}$. At present, the cure rate of breast cancer is still poor; the patients' 5 -year survival rate is about $70 \%$, which seriously endangers the physical and mental health of the majority of women ${ }^{[5]}$. However, the molecular mechanism of breast cancer remains not fully illustrated, particularly in the development of tumors. Therefore, it is of importance to explore the molecular mechanism of breast cancer and find potential therapeutic targets.

Non-coding RNAs (ncRNAs) are emerging as key molecules with promising potential to become new therapeutic targets for breast cancer and provide mechanistic insights into many undefined aspects of breast cancer. There has been a large number of studies reported that the aberrant expression of miRNA, long noncoding RNA (IncRNA) and circRNA is related to the initiation and development of various cancers, including breast cancer ${ }^{[6-9]}$. LncRNA are RNA molecules with a transcription length of more than 200 nucleotides, which are widely distributed in cytoplasm and / or nucleus. In recent years, accumulating evidences have pinpointed the importance of IncRNA-miRNA-mRNA network, which exert different biological functions to promote the progression of many cancers, i.e. pancreatic cancer ${ }^{[10]}$, colorectal cancer ${ }^{[11]}$, prostate cancer ${ }^{[12]}$, hepatocellular carcinoma ${ }^{[13,14]}$ and breast cancer ${ }^{[15]}$.

Prostate cancer-associated transcript 1 (PCAT1), a 2kb IncRNA transcribed from the genomic region of 8q24.21, is one of the most commonly detected IncRNAs as a proto-oncogene. proto-cancer, $P C A T$ 1was initially identified in prostate cancer by transcriptome sequencing. It is worth noting that PCAT1 is located in the 8q24, a "gene desert" region that close to the well documented prostate cancer risk SNP and $C M Y C$ oncogene, suggesting this gene locus and its frequent expansion in cancer may be related to other cancer biology aspects ${ }^{[16]}$. Some studies have found that the SNPs in PCAT1 were related to the incidence and development of the disease. For example, rs710886 affect the invasion and proliferation of endometriosis stem cells ${ }^{[17]}$; Gene polymorphism of PCAT1 can affect the

proliferation of esophageal squamous cell cancer cells ${ }^{[18]}$. However, there are few reports on the role and mechanism of PCAT1 SNPs in breast cancer.

Hereby, we evaluated the association between SNPs in PCAT1 and breast cancer susceptibility by genotyping, and investigated the potential underlying mechanism that how the SNPs in PCAT1 contribute to the development of breast cancer.

\section{Materials And Methods}

\section{Patient samples}

This is a case-control study, calculated by the PASS software and taking into account the possible loss, that a total of 504 treatment naïve breast cancer samples were included eventually. (from a top three hospital in Henan Province from March 2018 to December 2018) and 505 healthy controls (from the biological sample bank of Henan Key Laboratory of Oncology Epidemiology, matching the 
case frequency by age) were included. The case group samples included in the study were newly diagnosed with breast cancer by pathology from a third-grade A hospital in Henan Province, and all of them were Han Chinese women without any radiotherapy, chemotherapy or surgery. The control group was collected from the cardiovascular survey of Henan Province, excluding the family history of breast cancer and breast cancer-related diseases, and there was no kinship relationship between all the subjects. All samples were cryopreserved at $-80^{\circ} \mathrm{C}$ for later use. Basic information and clinical characteristics of the patients were obtained from the patients' medical records, including age, age of menarche, menopausal status, menopausal age, number of pregnancies, number of miscarriages, history of breast-feeding and family history of breast cancer and so on. The patients' hormone receptor status was also obtained for cases, including estrogen receptor (ER), progesterone receptor (PR) and human epidermal growth factor receptor-2 (HER-2) status, examinated by the method of IHC. The study was approved by the Ethics Review Committee of the Ethics Committee of Medical and Health Research of Zhengzhou University.

\section{DNA extraction, SNP selection and genotyping}

According to the manufacturer's instructions, the total DNA was extracted by using a DNA extraction kit (Shanghai laifeng biotechnology co. LTD) from the whole blood and stored at $-80^{\circ} \mathrm{C}$ for use. The PCAT1 functional SNP and tag SNP were obtained through the website NCBI (accessed in December 2017), IncRNASNP2 and software Haploview, and then the SNPs were verified by NCBI, Ensembl database and 1000genomes according to minor allele frequency (MAF) of $>0.05$ in CHB population, and finally 8 functional regulatory regions SNPs and tag SNPs were determined, the basic information of these 8 SNPs is shown in Table S1. Based on the characteristics of SNP sequence and the cost performance of the typing, After the grading of SNP before typing by the biological company, SNP typing methods were divided into three types, specifically as follows: rs17762938, rs7823297, rs9656964, rs1551513, rs1551514 sites were genotyped with SNPscan ${ }^{\text {TM }}$ multiple SNP typing kit; rs117117537 and rs785003 sites were genotyped using imLDR ${ }^{\text {TM }}$ multiple SNP typing kit; the polymerase chain reaction-restriction fragment-length polymorphism (PCR-RFLP) was used to genotype rs4473999 samples and $10 \%$ of all SNP typings are sampled for gene sequencing to ensure the accuracy of typing.

\section{Bioinformatics}

1) Secondary structure prediction

Online software RNAfold was used to predict the secondary structure of significant SNPs and observe whether there were changes in the secondary structure before and after the mutation(http://rna.tbi.univie.ac.at//cgi-bin/RNAWebSuite/RNAfold.cgi).

2) Function prediction

LncRNASNP2 was used to predict the binding capacity of miRNA that SNP might affect, as shown in Table S2.

\section{Quantitative real-time PCR analysis (qRT-PCR)}

Total plasma RNA was extracted from randomly selected healthy controls with TRIzol reagent, and then DNA was removed with Takara reagent kit and RNA was reversely transcribed into CDNA. The relative expression of PCAT1 in three different genotypes of SNP rs4473999 and rs 1551514 were determined by qRT-PCR with the method of SYBR-green in the ABI Prism 7500 Fast Real-Time PCR System. The relative expression of PCAT1 was calibrated by GAPDH as the endogenous control and present as the $2^{-\triangle C T}$ value. The sequence of primers used was listed in Table S3.

\section{Dual-luciferase reporter assay}

According to the prediction of LncRNASNP2, the mutated PCAT1-rs4473999 may loss the binding site of miR-149-5p. In this study, HEK 293 T cells with high MOI transfection and recognized by double luciferase assay were used to validate the binding of SNP and miRNA. The transfection was performed in a 12-well plate when the HEK 293T cells were at a confluence of $40 \%$. The wild pmirGLO plasmid or mutated pmirGLO plasmid and miR-149-5p mimic or mir-NC were transfected by using the riboFECT ${ }^{\mathrm{TM}} \mathrm{CP}_{\text {kit. Fluorescence was }}$ detected 72 hours after transfection, and the relative activity of luciferase was calculated according to the instructions using a dual luciferase reporter assay system based on firefly/renilla fluorescence.

CCK8, Scratch and Transwell assay in miR-149-5p interference and overexpression lentiviral vectors were constructed and transfected into breast cancer MCF-7, MDA-MB-231 cells) and screened for stable strain. Then qPCR was performed to determine the efficiency of 
miRNA interference and overexpression. CCK8, transwell and scratch assay were performed to evaluate the effects of interfering and overexpressing miR-149-5p on proliferation, invasion and migration in MCF-7 and MDA-MB-231 cells respectively.

\section{Statistical analysis}

The distribution between the case and the control group was compared with the continuous variable using the t test, and the categorical variable was analyzed by the Chi-square test. Susceptibility analysis and stratified analysis of basic features between SNP and breast cancer were performed using multi-factor unconditional logistic regression analysis to calculate the corresponding odds ratio ( $O R$ ) with 95\% confidence intervals (95\% Cl). MDR software was used to predict the interaction between SNP and environmental factors; The haplotype analysis was performed using SHEsis online software ${ }^{[19]}$; false positive reporter rate analysis was used to verify the authenticity of the results obtained. The expression of PCAT1 in different groups was compared by using a $t$-test with a $p$-value of $<0.05$ considered as significant. The double luciferase activities comparison between different groups was performed by using a t-test statistics. In CCK8 experiment, independent sample t test was used to analyze the difference of OD value between different groups. In the cell scratch and transwell assay experiment, $t$ test was used to analyze the difference of the cell scratch healing rate and the number of invaded cells between different groups.

\section{Results}

\section{Clinic characters of the patients}

We collected the basic information of $504 \mathrm{BC}$ cases and 505 healthy controls into the analysis, including their disease on-set age, menarche age, menopause status, menopause age, reproductive history, number of abortions, breastfeeding history, family history and hormone receptor status (Table1). A loistics analysis shows the age of menarche was different between the BC patients and the healthy controls ( $P=0.030)$, multiple pregnancy (OR: 1.964, 95\%Cl $\otimes 1.355-2.796)$ and the family history of breast cancer (OR=1.869 $95 \% \mathrm{Cl}$ : 1.116 3.130) may be related to the increased risk of breast cancer $\ a$ history of breastfeeding $(0 R=0.724,95 \% \mathrm{Cl}$ : $0.535-0.980)$ may be related to the reduced risk of breast cancer.

\section{Susceptibility analysis}

The correlation analysis between PCAT1 SNPs genotype and breast cancer susceptibility was present in Table 2 . The analysis was performed in four different models (codominance, dominant, recessive and overdominance) respectively. In the adjusted logistics regression analysis, SNP rs4473999 was the risk factor of breast cancer in the overdominant model $(\mathrm{OR}=1.360,95 \% \mathrm{Cl}$ : $1.009-1.832)$. To ensure the representativeness of the control group, the Hardy-Weinberg Balance Test was applied. It is apparent that all the control samples of SNPs were representative $(P>0.05)$.

\section{Stratified analysis}

The stratified analysis consists of three aspects of stratification. The first is to stratify the patients' clinical information in the model, including age, menarche age, menopause status, menopause age, number of pregnancies, number of abortions, breastfeeding history and family history, as shown in Table 3. In the dominant model, SNP rs117117537 was a risk factor for breast cancer in menopausal age $>50$ years $(\mathrm{OR}=2.41395 \% \mathrm{Cl}$ : $1.057-5.508)$; rs4473999 was a risk factor for breast cancer in menopausal age $>50$ years $(\mathrm{OR}=2.137$ 95\%Cl: 1.065-4.286) and abortion times <2 (OR=1.510 95\% Cl: 1.045-2.181). Secondly, the hormone receptor status of case breast cancer patients was stratified. As shown in Table S4, only TT genotype (OR=0.158 95\% Cl: 0.029-0.864) of SNP rs785003 was associated with HER-2 receptor status. And finally, the data was stratified according to the molecular subtypes of breast cancer, that the analysis shows GA+AA genotype (OR=0.671 95\% Cl: 0.452-0.997) of SNP rs1551514 was correlate with luminal type breast cancer (Table S5).

\section{Haplotype analysis and Gene-reproductive interaction}

Haplotype analysis was used to determine the joint effect between SNPs of IncRNA, and the frequencies less than $3 \%$ were not present (Each haplotype was divided into two groups, the haplotype group and the non-haplotype group. The reference group was the non-

haplotype group). As shown in Table 4, the $\mathrm{G}_{\mathrm{rs} 1551514} \mathrm{~T}_{\mathrm{rs} 1551513} \mathrm{C}_{\mathrm{rs} 447399} \mathrm{C}_{\mathrm{rs} 9656964} \mathrm{~T}_{\mathrm{rs} 17762938} \mathrm{C}_{\mathrm{rs} 7823297} \mathrm{~T}_{\mathrm{rs} 785003} \mathrm{~T}_{\text {rs } 117117537}$ haplotype of PCAT1 was associated with increased risk of breast cancer (OR=1.614 95\%Cl: 1.116-2.333). Table 5 demonstrated the results of the interaction between genetic and reproductive factors analyzed using MDR software. Among the 1 to 3 order interaction models produced by fitting, the 3 order model was the optimal model, the average accuracy of training set was 0.6137 , the average precision of test set 
was 0.5837 and the consistency rate of ten fold cross validation is 10/10. And the model includes three factors, rs 4473999 , number of pregnancies and breastfeeding history, which manifested that there was interaction between genes and reproductive factors.

\section{False positive report probability (FPRP)}

In this study, FPRP analysis ${ }^{[20]}$ was used to evaluate the reliability of the positive results of PCAT1 SNPs associated with breast cancer susceptibility. The critical value of FPRP was set as 0.5 . From the data in Table S6, it is apparent that when the prior probability was 0.25 , the FPRP value of rs 4473999 , rs 1551514 and rs 117117537 positive results were all lower than the critical value, suggesting that rs4473999, rs1551514 and rs117117537 may have a real correlation with breast cancer susceptibility.

\section{Real-time fluorescent quantitative PCR (qPCR)}

From the results of qPCR in Figure 1 we can see that for rs 4473999, CC, CT and TT genotypes, 41, 21 and 14 samples were randomly selected for $\mathrm{qPCR}$, respectively; The relative expression of $P C A T 1$ in the three genotypes was $1.50 \pm 0.70,1.07 \pm 0.83$ and $0.75 \pm 0.64$, respectively. Pairwise comparisons showed that difference between CC vs CT $(P=0.038)$ and CC vs TT $(P=0.001)$ were statistically significant, and the expression levels of PCAT1 in CT and TT groups were lower than that in CC group. For rs1551514, 25 samples were GG genotype, the relative expression of PCAT1 was $1.63 \pm 0.97 ; 33$ samples were GA genotype, the relative expression of PCAT1 was $1.10 \pm 0.61 ; 13$ samples were AA genotype, the relative expression of PCAT1 was $0.94 \pm 0.79$; and the differences between GG vs GA $(P=0.021)$ and $\mathrm{GG}$ vs AA $(P=0.033)$ were both statistically significant.

\section{Dual-luciferase reporter assay}

Figure 2 showed the results of the dual-luciferase reporting experiment. The luciferase activity of NC group is significantly higher than the miR-149-5p group ( $P=0.001)$. Simultaneously, the luciferase activity of mutant-type (MUT) plus miR-149-5p group is significantly higher than the wild-type (WT) plus miR-149-5p group $(P<0.001)$. These results indicate the combination of rs4473999-WT and miR-149$5 p$, but there was no evidence for the combination between the rs4473999-MUT and miR-149-5p, which was consistent with the previous prediction.

\section{Cytological experiment}

The results of verification of the knockdown and overexpression stable transgenic effects of miR-149-5p combined with PCAT1 SNP showed that miR-149-5p was knocked down by about 50 and overexpressed by about 2 times in MDA-MB-231 cells and MCF-7 cells (Figure S1). CCK8 assay showed that compared with the negative control(NC) group, the OD values of MDA-MB-231 cells in the miR149-5p low-expression group were lower at 450nm at 24h $(P=0.002), 48 h(P=0.002), 72 h(P=0.002)$ and $96 h(P<0.001), 0 D$ values of MDA-MB-231 cells in the miR-149-5p high expression group were higher at 450nm at 24h ( $P=0.020), 48 \mathrm{~h}(P=0.016), 72 \mathrm{~h}(\mathrm{P}=0.035)$ and 96h ( $P=0.016)$, as shown in Figure 3(A); Figure 3(B) showed the results of the CCK8 experiment of MCF-7. The results show that compared with the NC group, MCF-7 cells in the miR-149-5p low expression group at $450 \mathrm{~nm}$ for $24 \mathrm{~h}(\mathrm{P}<0.001), 48 \mathrm{~h}(\mathrm{P}=0.016), 72 \mathrm{~h}$ $(P<0.001)$ and $96 \mathrm{~h}(\mathrm{P}<0.001)$ had lower OD values; MCF-7 cells in the miR-149-5p high expression group at $450 \mathrm{~nm}$ for $24 \mathrm{~h}(\mathrm{P}=0.013)$, $48 \mathrm{~h}(\mathrm{P}=0.014), 72 \mathrm{~h}(\mathrm{P}<0.001)$ and $96 \mathrm{~h}(\mathrm{P}=0.002)$ had higher OD values. The scratch healing results of MDA-MB-231 cells at $0 \mathrm{~h}$ and 48 $\mathrm{h}$ (Figure 4A)showed that compared with the NC group, the healing rate of MDA-MB-231 cells in the group with low miR-149-5p expression was lower $(P=0.023)$, and that of MDA-MB-231 cells in the group with high miR-149-5p expression was higher $(P=0.043)$; Similarly, the healing rate of MCF-7 cells in the low-expression group of miR-149-5p was lower $(P=0.021)$, while the healing rate of MCF-7 cells in the high-expression group of miR-149-5p was higher ( $\mathrm{P}=0.014)$ (Figure 4B). The results of cell invasion experiments showed that in both MDA-MB-231 cells and MCF-7 cells, the number of cell invasion in the miR-149-5p low expression group was lower than that of the NC group, and the cell invasion number in the miR-149-5p high expression group was higher than the NC group (Figure 5).

\section{Discussion}

Through a series of experiments, we first report the SNP of PCAT1 was related to the susceptibility of breast cancer that rs 117117537 $(\mathrm{OR}=2.413,95 \% \mathrm{Cl}: 1.057-5.508)$ and $\mathrm{rs} 4473999(\mathrm{OR}=2.13795 \% \mathrm{Cl}: 1.065-4.286)$ were identified as risk factors for breast cancer when the menopausal age was $\geq 50$. In addition, rs785003 was associated with HER2 status of breast cancer $(P=0.033)$ and rs 1551514 was related to luminal type breast cancer $(P=0.048)$. The haplotype GTCCTCTT of PCAT1-SNPs is a risk factor for breast cancer ( $\mathrm{OR}=1.61495 \% \mathrm{Cl}$ : $1.116-2.333)$. The rs4473999, associated with number of pregnancies and breastfeeding history, was also identified as a risk factor for breast cancer $(\mathrm{OR}=2.48795 \% \mathrm{Cl}$ : $1.929-3.206)$. The false positive analysis confirmed the reliability of these results. Preliminary functional assays demonstrated that the relative expression of PCAT1 was different between SNP rs1551514 
or rs4473999 genotypes, mainly manifested in WT vs MUT $(P=0.021, P=0.038)$ and WT vs heterozygous $(P=0.033, P=0.001)$; In addition, miR-149-5p was shown to bind the wild type of rs4473999 rather than mutant type by double luciferase reporter gene assay. The cell function verification results showed that low expression of miR-149-5p could inhibit the proliferation, invasion and migration of breast cancer cells, while high expression could promote the proliferation, invasion and metastasis of breast cancer cells.

It has been reported that single nucleotide polymorphism (SNPs) of IncRNA could be associated with cancer susceptibility. For example, Peng R et al. confirmed that IncRNA MALAT1's tagSNPs (rs3200401, rs619586) were related to the susceptibility of breast cancer through the change of serum mRNA expression level[6]; SNP rs2073859 of LIMK2 may affect the risk of bladder cancer by specifically up- or down-regulating miR-135a ${ }^{[7]}$. Bayram S et al. found that the polymorphism of HOTAIR rs 920778 gene may play an important role in the genetic susceptibility and invasiveness of breast cancer in the Turkish population ${ }^{[21]}$. Currently some studies have found that the SNPs in PCAT1 were associated with susceptibility of different cancers, i.e. rs1902432 and prostate cancer ${ }^{[22]}$, rs710886 and bladder cancer ${ }^{[23]}$, rs2632159 and colorectal cancer ${ }^{[24]}$. However, no study has found the association between any SNP in PCAT1 and breast cancer susceptibility. Here we first showed that rs4473999 genotype CT is associated with an increased risk of breast cancer in a super dominant model, and its mutant genotype CT + TT showed a higher incidence of breast cancer when the menopausal age was $\geq 50$ years and the number of miscarriages is less than 2 compared with homozygous wild-type CC. This is the first study that demonstrated the association between the SNPs of PCAT1 and breast cancer susceptibility.

In this study, the dual luciferase reporter gene experiment was used to verify whether the rs 4473999 mutation affected the binding ability of PCAT1 and miR-149-5p. The results showed that PCAT1 could bind to miR-149-5p when rs4473999 carried the wild-type gene C, and after the mutation, there was no evidence that PCAT1 could bind to miR-149-5p, which was consistent with the predicted results of LncRNASNP2. That is, the mutation of rs4473999 could affect the binding ability of PCAT1 and miR-149-5p. Studies have shown that miR-149-5p is closely related to the development of a variety of cancers, such as liver cancer ${ }^{[25]}$, nasopharyngeal carcinoma ${ }^{[26]}$, nonsmall cell lung cancer ${ }^{[27]}$, etc., but there is no research on miR-149-5p related to breast cancer progression. In this study, CCK8, scratch experiment and transwell experiment were used to investigate the effect of miR-149-5p combined with rs4473999 of PCAT1 on the proliferation, migration and invasion of breast cancer cells; the results showed that the low expression of miR-149-5p may inhibit the proliferation, migration and invasion of breast cancer cells; the overexpression of miR-149-5p may promote the proliferation, migration and invasion of breast cancer cells.

This study is the first report on the association between PCAT1 genetic variant SNPs and breast cancer susceptibility. Based on bioinformatics prediction and experimental verification, it is found that PCAT1 rs4473999 may affect the proliferation, invasion and migration of breast cancer cells by regulating miR-149-5p. The main advantages of this study are reflected in the following aspects, firstly, all the cases included in this study are new cases, which is conducive to controlling the incidence bias; secondly, the control group is randomly selected from the chronic disease investigation project of 20,000 community in Henan province, which can reduce the selection bias; finally, genotyping of all SNPs were randomly selected for $10 \%$ of samples for sequencing verification and in the cell function experiment, all experiments were repeated more than three times, therefore, the results of this study have authenticity and reliability. Nevertheless, this study still has some limitations, for one thing, all the subjects included in this study were Chinese Han, so the results of this study in other populations need to be further verified; for another, the effect of PCAT1 genetic variation SNPs on breast cancer was only preliminarily explored in this study, the further function of PCAT1 genetic variation SNPs needs to be explored.

In summary, our study shows the PCAT1 gene polymorphism is associated with the occurrence of breast cancer, which may help to improve our understanding about the susceptibility of breast cancer. In addition, the PCAT1 rs4473999 C/T variant may affect the binding of miR-149-5p to PCAT1, subsequently, affecting the susceptibility of breast cancer cells by regulating the expression of miR149-5p.

\section{Declarations}

\section{Ethical Approval and Consent to participate}

The study was approved by the Ethics Review Committee of the Ethics Committee of Medical and Health Research of Zhengzhou University.

\section{Consent for publication}

We agree to authorize the article for publication 


\section{Availability of supporting data}

Not applicable

Conflict of Interest: The authors declare that there are no conflicts of interest.

\section{Funding}

This study was supported by the Support Program for Scientific and Technological Innovation Talents of Henan Universities (19HASTIT005), the Science and Technology Research Project of Henan Province (192102310088, 19A32000820, SBGJ2018089) and the National Natural Science Foundation of China (U1604168).

\section{Authors' contributions}

Yanli Wang and Qiuyu Sun completed the experiment, analyzed the data and wrote the manuscript. Linping Xu, Kaijuan Wang and Chunhua Song conceived the overall idea of the paper and revised the draft. Other authors participated in the experimental design and data processing. All authors have read and approved the final manuscript.

Acknowledgements: Informed consent was obtained from all individual participants included in the study.

\section{References}

1. World Health Organization. Global Health Observatory. Geneva: World Health Organization; 20182018 [cited 2018 June 21]. Available from: who.int/gho/database/en/.

2. Sung H, Ferlay J, Siegel RL, et al. Global cancer statistics 2020: GLOBOCAN estimates of incidence and mortality worldwide for 36 cancers in 185 countries[J]. 2021:1-41

3. Bray F, McCarron P, Parkin DM. The changing global patterns of female breast cancer incidence and mortality[J]. Breast cancer research : BCR. 2004,6(6):229-239

4. Fan L, Strasser-Weippl K, Li JJ, et al. Breast cancer in China[J]. The Lancet Oncology. 2014,15(7):e279-289

5. Hart CD, Migliaccio I, Malorni L, et al. Challenges in the management of advanced, ER-positive, HER2-negative breast cancer[J]. Nature reviews Clinical oncology. 2015,12(9):541-552

6. Peng R, Luo C, Guo Q, et al. Association analyses of genetic variants in long non-coding RNA MALAT1 with breast cancer susceptibility and mRNA expression of MALAT1 in Chinese Han population[J]. Gene. 2018,642:241-248

7. Wang W, Yang C, Nie H, et al. LIMK2 acts as an oncogene in bladder cancer and its functional SNP in the microRNA-135a binding site affects bladder cancer risk[J]. International journal of cancer. 2019,144(6):1345-1355

8. Li D, Yang R, Yang L, et al. circANKS1B regulates FOXM1 expression and promotes cell migration and invasion by functioning as a sponge of the miR-149 in colorectal cancer[J]. OncoTargets and therapy. 2019,12:4065-4073

9. Luo X, Wang GH, Bian ZL, et al. Long non-coding RNA CCAL/miR-149/FOXM1 axis promotes metastasis in gastric cancer[J]. Cell death \& disease. 2018,9(10):993

10. Li H, Wang X, Wen C, et al. Long noncoding RNA NORAD, a novel competing endogenous RNA, enhances the hypoxia-induced epithelial-mesenchymal transition to promote metastasis in pancreatic cancer[J]. Molecular cancer. 2017,16(1):169

11. Chen DL, Lu YX, Zhang JX, et al. Long non-coding RNA UICLM promotes colorectal cancer liver metastasis by acting as a ceRNA for microRNA-215 to regulate ZEB2 expression[J]. Theranostics. 2017,7(19):4836-4849

12. Ramalho-Carvalho J, Fromm B, Henrique R, et al. Deciphering the function of non-coding RNAs in prostate cancer[J]. Cancer metastasis reviews. 2016,35(2):235-262

13. Li T, Xie J, Shen C, et al. Amplification of Long Noncoding RNA ZFAS1 Promotes Metastasis in Hepatocellular Carcinoma[J]. Cancer research. 2015,75(15):3181-3191

14. Tang J, Zhuo H, Zhang X, et al. A novel biomarker Linc00974 interacting with KRT19 promotes proliferation and metastasis in hepatocellular carcinoma[J]. Cell death \& disease. 2014,5:e1549

15. Huang X, Xie X, Liu P, et al. Adam12 and Inc015192 act as ceRNAs in breast cancer by regulating miR-34a[J]. Oncogene. 2018,37(49):6316-6326 
16. Prensner JR, lyer MK, Balbin OA, et al. Transcriptome sequencing across a prostate cancer cohort identifies PCAT-1, an unannotated lincRNA implicated in disease progression[J]. Nature biotechnology. 2011,29(8):742-749

17. Wang L, Xing Q, Feng T, et al. SNP rs710886 A>G in long noncoding RNA PCAT1 is associated with the risk of endometriosis by modulating expression of multiple stemness-related genes via microRNA-145 signaling pathway[J]. Journal of cellular biochemistry. 2019

18. Huang L, Wang Y, Chen J, et al. Long noncoding RNA PCAT1, a novel serum-based biomarker, enhances cell growth by sponging miR-326 in oesophageal squamous cell carcinoma[J]. Cell death \& disease. 2019,10(7):513

19. Shi YY, He L. SHEsis, a powerful software platform for analyses of linkage disequilibrium, haplotype construction, and genetic association at polymorphism loci[J]. Cell research. 2005,15(2):97-98

20. Wacholder S, Chanock S, Garcia-Closas M, et al. Assessing the probability that a positive report is false: an approach for molecular epidemiology studies[J]. Journal of the National Cancer Institute. 2004,96(6):434-442

21. Bayram S, Sumbul AT, Batmaci CY, et al. Effect of HOTAIR rs 920778 polymorphism on breast cancer susceptibility and clinicopathologic features in a Turkish population[J]. Tumour biology : the journal of the International Society for Oncodevelopmental Biology and Medicine. 2015,36(5):3863-3870

22. Yuan Q, Chu H, Ge Y, et al. LncRNA PCAT1 and its genetic variant rs1902432 are associated with prostate cancer risk[J]. Journal of Cancer. 2018,9(8):1414-1420

23. Lin Y, Ge Y, Wang Y, et al. The association of rs710886 in IncRNA PCAT1 with bladder cancer risk in a Chinese population[J]. Gene. 2017,627:226-232

24. Yang ML, Huang Z, Wu LN, et al. IncRNA-PCAT1 rs2632159 polymorphism could be a biomarker for colorectal cancer susceptibility[J]. 2019,39(7)

25. Dong J, Teng F, Guo W, et al. IncRNA SNHG8 Promotes the Tumorigenesis and Metastasis by Sponging miR-149-5p and Predicts Tumor Recurrence in Hepatocellular Carcinoma[J]. Cellular physiology and biochemistry : international journal of experimental cellular physiology, biochemistry, and pharmacology. 2018,51(5):2262-2274

26. Kong YG, Cui M, Chen SM, et al. LncRNA-LINC00460 facilitates nasopharyngeal carcinoma tumorigenesis through sponging miR149-5p to up-regulate IL6[J]. Gene. 2018,639:77-84

27. Li J, Li Y, Wang B, et al. LncRNA-PCAT-1 promotes non-small cell lung cancer progression by regulating miR-149-5p/LRIG2 axis[J]. Journal of cellular biochemistry. 2018

\section{Tables}

Table 1. Basic characteristics of 504 breast cancer cases and 505 healthy controls 


\begin{tabular}{|c|c|c|c|c|}
\hline \multirow[t]{2}{*}{ Variables } & Cases (\%) & Controls (\%) & \multirow[t]{2}{*}{$P^{b}$} & \multirow[t]{2}{*}{ OR $(95 \% \mathrm{Cl})$} \\
\hline & $n=504$ & $n=505$ & & \\
\hline Age $(\bar{x} \pm s)$ & $48.00 \pm 9.85$ & $48.15 \pm 9.61$ & $0.806^{\mathrm{a}}$ & \\
\hline Menarche age $\llbracket \bar{x} \pm s \rrbracket$ & $14.21 \pm 1.70$ & $13.97 \pm 1.75$ & $0.030^{\mathrm{a}}$ & \\
\hline Menopausal age $(\bar{x} \pm s)$ & $48.60 \pm 3.90$ & $48.72 \pm 3.70$ & $0.760^{\mathrm{a}}$ & \\
\hline \multicolumn{5}{|l|}{ Menopausal status } \\
\hline Pre-menopausal & $320(63.5)$ & $294(58.2)$ & & 1 \\
\hline Post-menopausal & $184(36.5)$ & $211(41.8)$ & 0.086 & $0.801(0.622-1.032)$ \\
\hline \multicolumn{5}{|l|}{ Number of pregnancies } \\
\hline$<2$ & $53(10.5)$ & $94(18.6)$ & & 1 \\
\hline$\geq 2$ & 451 (89.5) & $411(81.4)$ & $<0.001$ & $1.964(1.355-2.796)$ \\
\hline \multicolumn{5}{|l|}{ Number of abortions } \\
\hline$<2$ & 340 (67.5) & $345(68.3)$ & & 1 \\
\hline$\geq 2$ & $164(32.5)$ & $160(31.7)$ & 0.771 & $1.040(0.798-1.355)$ \\
\hline \multicolumn{5}{|l|}{ Breastfeeding } \\
\hline No & $121(24.0)$ & $94(18.6)$ & & 1 \\
\hline Yes & $383(76.0)$ & $411(81.4)$ & 0.037 & $0.724(0.535-0.980)$ \\
\hline \multicolumn{5}{|l|}{ Family history } \\
\hline No & 461 (91.5) & $481(95.2)$ & & 1 \\
\hline Yes & $43(8.5)$ & $24(4.8)$ & 0.017 & $1.869(1.116-3.130)$ \\
\hline \multicolumn{5}{|l|}{ ER status } \\
\hline Negative & $149(30.3)$ & & & \\
\hline Positive & $342(69.7)$ & & & \\
\hline \multicolumn{5}{|l|}{ PR status } \\
\hline Negative & 191(39.1) & & & \\
\hline Positive & $298(60.9)$ & & & \\
\hline \multicolumn{5}{|l|}{ HER-2 status } \\
\hline Negative & 138(29.6) & & & \\
\hline Positive & $329(70.4)$ & & & \\
\hline
\end{tabular}

a $t$ test

${ }^{\mathrm{b}} \chi^{2}$ test, Bilateral $P<0.05$ was statistically different

Table 2. Association analysis between genotypes of PCAT1 SNPs and susceptibility to breast cancer

a Unadjusted $P$ value in logistic regression analysis

${ }^{\mathrm{b}}$ Logistic regression analysis adjusted the $P$ values of age, menarche age, menopausal status, frequency of pregnancy, frequency of abortion, history of breastfeeding and family history. 


\begin{tabular}{|c|c|c|c|c|c|c|c|c|c|}
\hline SNP & Genetic model & Genotype & $\begin{array}{l}\text { cases } \\
₫ 504 \rrbracket\end{array}$ & $\begin{array}{l}\text { controls } \\
\text { ه505『 }\end{array}$ & $\begin{array}{l}\text { Unadjusted } \\
\text { OR }(95 \% \mathrm{Cl})\end{array}$ & $P^{a}$ & $\begin{array}{l}\text { Adjusted OR } \\
(95 \% \mathrm{Cl})\end{array}$ & $P^{b}$ & $P^{C}$ \\
\hline \multirow[t]{9}{*}{ rs1551513 } & Codominance & $\mathrm{TT}$ & 329 & 348 & 1 & & 1 & & 0.769 \\
\hline & & $\mathrm{TC}$ & 159 & 139 & $\begin{array}{l}1.210(0.921- \\
1.590)\end{array}$ & 0.171 & $\begin{array}{l}1.193(0.890- \\
1.599)\end{array}$ & 0.238 & \\
\hline & & $\mathrm{CC}$ & 16 & 18 & $\begin{array}{l}0.940(0.472- \\
1.875)\end{array}$ & 0.861 & $\begin{array}{l}0.931(0.442- \\
1.959)\end{array}$ & 0.850 & \\
\hline & Dominant & $\mathrm{TT}$ & 329 & 348 & 1 & & 1 & & \\
\hline & & $\mathrm{TC}+\mathrm{CC}$ & 175 & 157 & $\begin{array}{l}1.179(0.906- \\
1.534)\end{array}$ & 0.220 & $\begin{array}{l}1.162(0.877- \\
1.541)\end{array}$ & 0.295 & \\
\hline & Recessive & $\mathrm{TT}+\mathrm{TC}$ & 488 & 487 & 1 & & 1 & & \\
\hline & & $\mathrm{CC}$ & 16 & 18 & $\begin{array}{l}0.887(0.447- \\
1.760)\end{array}$ & 0.732 & $\begin{array}{l}0.885(0.422- \\
1.855)\end{array}$ & 0.747 & \\
\hline & Overdominance & $\mathrm{TT}+\mathrm{CC}$ & 345 & 366 & 1 & & 1 & & \\
\hline & & $\mathrm{TC}$ & 159 & 139 & $\begin{array}{l}1.214(0.925- \\
1.591)\end{array}$ & 0.162 & $\begin{array}{l}1.197(0.895- \\
1.601)\end{array}$ & 0.226 & \\
\hline \multirow[t]{9}{*}{ rs17762938 } & Codominance & TT & 329 & 344 & 1 & & 1 & & 0.945 \\
\hline & & $\mathrm{TC}$ & 159 & 143 & $\begin{array}{l}1.163(0.886- \\
1.526)\end{array}$ & 0.277 & $\begin{array}{l}1.154(0.862- \\
1.545)\end{array}$ & 0.335 & \\
\hline & & $\mathrm{CC}$ & 16 & 18 & $\begin{array}{l}0.929(0.466- \\
1.853)\end{array}$ & 0.835 & $\begin{array}{l}0.922(0.438- \\
1.942)\end{array}$ & 0.831 & \\
\hline & Dominant & $\mathrm{TT}$ & 329 & 344 & 1 & & 1 & & \\
\hline & & $\mathrm{TC}+\mathrm{CC}$ & 175 & 161 & $\begin{array}{l}1.137(0.875- \\
1.477)\end{array}$ & 0.338 & $\begin{array}{l}1.128(0.852- \\
1.493)\end{array}$ & 0.401 & \\
\hline & Recessive & $\mathrm{TC}+\mathrm{TT}$ & 488 & 487 & 1 & & 1 & & \\
\hline & & $\mathrm{CC}$ & 16 & 18 & $\begin{array}{l}0.887(0.447- \\
1.760)\end{array}$ & 0.732 & $\begin{array}{l}0.885(0.422- \\
1.855)\end{array}$ & 0.747 & \\
\hline & Overdominance & $\mathrm{TT}+\mathrm{CC}$ & 345 & 362 & 1 & & 1 & & \\
\hline & & $\mathrm{TC}$ & 159 & 143 & $\begin{array}{l}1.167(0.891- \\
1.528)\end{array}$ & 0.263 & $\begin{array}{l}1.158(0.867- \\
1.548)\end{array}$ & 0.320 & \\
\hline \multirow[t]{9}{*}{ rs7823297 } & Codominance & $\mathrm{CC}$ & 329 & 343 & 1 & & 1 & & 0.983 \\
\hline & & $\mathrm{TC}$ & 159 & 144 & $\begin{array}{l}1.151(0.877- \\
1.510)\end{array}$ & 0.310 & $\begin{array}{l}1.147(0.857- \\
1.536)\end{array}$ & 0.356 & \\
\hline & & $\mathrm{TT}$ & 16 & 18 & $\begin{array}{l}0.927(0.465- \\
1.848)\end{array}$ & 0.829 & $\begin{array}{l}0.921(0.437- \\
1.939)\end{array}$ & 0.828 & \\
\hline & Dominant & $\mathrm{CC}$ & 329 & 343 & 1 & & 1 & & \\
\hline & & $\mathrm{TC}+\mathrm{TT}$ & 175 & 162 & $\begin{array}{l}1.126(0.867- \\
1.463)\end{array}$ & 0.374 & $\begin{array}{l}1.122(0.847- \\
1.485)\end{array}$ & 0.423 & \\
\hline & Recessive & $\mathrm{TC}+\mathrm{CC}$ & 488 & 487 & 1 & & 1 & & \\
\hline & & $\mathrm{TT}$ & 16 & 18 & $\begin{array}{l}0.887(0.447- \\
1.760)\end{array}$ & 0.732 & $\begin{array}{l}0.885(0.422- \\
1.855)\end{array}$ & 0.747 & \\
\hline & Overdominance & $\mathrm{CC}+\mathrm{TT}$ & 345 & 361 & 1 & & 1 & & \\
\hline & & $\mathrm{TC}$ & 159 & 144 & $\begin{array}{l}1.155(0.882- \\
1.513)\end{array}$ & 0.294 & $\begin{array}{l}1.151(0.862- \\
1.538)\end{array}$ & 0.340 & \\
\hline rs9656964 & Codominance & $\mathrm{CC}$ & 329 & 344 & 1 & & 1 & & 0.945 \\
\hline
\end{tabular}




\begin{tabular}{|c|c|c|c|c|c|c|c|c|c|}
\hline & & GC & 159 & 143 & $\begin{array}{l}1.163(0.886- \\
1.526)\end{array}$ & 0.277 & $\begin{array}{l}1.154(0.862- \\
1.545)\end{array}$ & 0.335 & \\
\hline & & GG & 16 & 18 & $\begin{array}{l}0.929(0.466- \\
1.853)\end{array}$ & 0.835 & $\begin{array}{l}0.922(0.438- \\
1.942)\end{array}$ & 0.831 & \\
\hline & Dominant & $\mathrm{CC}$ & 329 & 344 & 1 & & 1 & & \\
\hline & & $G C+G G$ & 175 & 161 & $\begin{array}{l}1.137(0.875- \\
1.477)\end{array}$ & 0.338 & $\begin{array}{l}1.128(0.852- \\
1.493)\end{array}$ & 0.401 & \\
\hline & Recessive & $\mathrm{GC}+\mathrm{CC}$ & 488 & 487 & 1 & & 1 & & \\
\hline & & GG & 16 & 18 & $\begin{array}{l}0.887(0.447- \\
1.760)\end{array}$ & 0.732 & $\begin{array}{l}0.885(0.422- \\
1.855)\end{array}$ & 0.747 & \\
\hline & Overdominance & $\mathrm{CC}+\mathrm{GG}$ & 345 & 362 & 1 & & 1 & & \\
\hline & & GC & 159 & 143 & $\begin{array}{l}1.167(0.891- \\
1.528)\end{array}$ & 0.263 & $\begin{array}{l}1.158(0.867- \\
1.548)\end{array}$ & 0.320 & \\
\hline rs785003 & Codominance & $\mathrm{CC}$ & 425 & 435 & 1 & & 1 & & 0.167 \\
\hline & & CT & 71 & 68 & $\begin{array}{l}1.069(0.747- \\
1.529)\end{array}$ & 0.716 & $\begin{array}{l}1.141(0.776- \\
1.676)\end{array}$ & 0.503 & \\
\hline & & TT & 8 & 2 & $\begin{array}{l}4.094(0.864- \\
19.391)\end{array}$ & 0.076 & $\begin{array}{l}4.996(0.992- \\
25.171)\end{array}$ & 0.051 & \\
\hline & Dominant & $\mathrm{CC}$ & 425 & 435 & 1 & & 1 & & \\
\hline & & $\mathrm{CT}+\mathrm{TT}$ & 79 & 70 & $\begin{array}{l}1.155(0.815- \\
1.637)\end{array}$ & 0.417 & $\begin{array}{l}1.248(0.859- \\
1.812)\end{array}$ & 0.248 & \\
\hline SNP & Genetic model & Genotype & cases $₫ 504 \rrbracket$ & & $\begin{array}{l}\text { Unadjusted } \\
\text { OR }(95 \% \mathrm{Cl})\end{array}$ & $P^{a}$ & $\begin{array}{l}\text { Adjusted OR } \\
(95 \% \mathrm{Cl})\end{array}$ & $P^{b}$ & $P^{C}$ \\
\hline & & & & ه505】 & & & & & \\
\hline & Recessive & $\mathrm{CT}+\mathrm{CC}$ & 496 & 503 & 1 & & 1 & & \\
\hline & & TT & 8 & 2 & $\begin{array}{l}4.056(0.857- \\
19.197)\end{array}$ & 0.077 & $\begin{array}{l}4.906(0.975- \\
24.690)\end{array}$ & 0.054 & \\
\hline & Overdominance & $\mathrm{CC}+\mathrm{TT}$ & 433 & 437 & 1 & & 1 & & \\
\hline & & CT & 71 & 68 & $\begin{array}{l}1.054(0.737- \\
1.508)\end{array}$ & 0.774 & $\begin{array}{l}1.122 \\
(0.764- \\
1.647)\end{array}$ & 0.558 & \\
\hline rs117117537 & Codominance & TT & 418 & 427 & 1 & & 1 & & 0.138 \\
\hline & & GG & 7 & 5 & $\begin{array}{l}1.105(0.782- \\
1.562)\end{array}$ & 0.570 & $\begin{array}{l}1.158(0.800- \\
1.675)\end{array}$ & 0.437 & \\
\hline & & GT & 79 & 73 & $\begin{array}{l}1.430(0.450- \\
4.542)\end{array}$ & 0.544 & $\begin{array}{l}1.489(0.423- \\
5.247)\end{array}$ & 0.536 & \\
\hline & Dominant & TT & 418 & 427 & 1 & & 1 & & \\
\hline & & $\mathrm{GT}+\mathrm{GG}$ & 86 & 78 & $\begin{array}{l}1.126(0.806- \\
1.574)\end{array}$ & 0.486 & $\begin{array}{l}1.179(0.824- \\
1.686)\end{array}$ & 0.369 & \\
\hline & Recessive & $\mathrm{GT}+\mathrm{TT}$ & 497 & 500 & 1 & & 1 & & \\
\hline & & GG & 7 & 5 & $\begin{array}{l}1.408(0.444- \\
4.467)\end{array}$ & 0.561 & $\begin{array}{l}1.459(0.415- \\
5.132)\end{array}$ & 0.556 & \\
\hline & Overdominance & $\mathrm{TT}+\mathrm{GG}$ & 425 & 432 & 1 & & 1 & & \\
\hline & & GT & 79 & 73 & $\begin{array}{l}1.100(0.779- \\
1.554)\end{array}$ & 0.588 & $\begin{array}{l}1.152(0.797- \\
1.667)\end{array}$ & 0.452 & \\
\hline rs1551514 & Codominance & GG & 173 & 165 & 1 & & 1 & & 0.372 \\
\hline & & GA & 254 & 256 & $\begin{array}{l}0.946(0.719- \\
1.246)\end{array}$ & 0.694 & $\begin{array}{l}0.916(0.681- \\
1.233)\end{array}$ & 0.564 & \\
\hline
\end{tabular}




\begin{tabular}{|c|c|c|c|c|c|c|c|c|c|}
\hline & & AA & 77 & 84 & $\begin{array}{l}0.874(0.600- \\
1.273 \rrbracket\end{array}$ & 0.483 & $\begin{array}{l}0.868(0.582- \\
1.294)\end{array}$ & 0.487 & \\
\hline & Dominant & GG & 173 & 165 & 1 & & 1 & & \\
\hline & & $\mathrm{GA}+\mathrm{AA}$ & 331 & 340 & $\begin{array}{l}0.929(0.715- \\
1.206)\end{array}$ & 0.578 & $\begin{array}{l}0.904(0.682- \\
1.198)\end{array}$ & 0.483 & \\
\hline & Recessive & $\mathrm{GA}+\mathrm{GG}$ & 427 & 421 & 1 & & 1 & & \\
\hline & & AA & 77 & 84 & $\begin{array}{l}0.904(0.645- \\
1.266)\end{array}$ & 0.557 & $\begin{array}{l}0.915(0.640- \\
1.308)\end{array}$ & 0.625 & \\
\hline & Overdominance & $A A+G G$ & 250 & 249 & 1 & & 1 & & \\
\hline & & GA & 254 & 256 & $\begin{array}{l}0.988(0.772- \\
1.265)\end{array}$ & 0.925 & $\begin{array}{l}0.960(0.737- \\
1.252)\end{array}$ & 0.765 & \\
\hline \multirow[t]{9}{*}{ rs4473999 } & Codominance & $\mathrm{CC}$ & 362 & 381 & 1 & & 1 & & 0.519 \\
\hline & & CT & 129 & 103 & $\begin{array}{l}1.318(0.980- \\
1.773)\end{array}$ & 0.068 & $\begin{array}{l}1.277(0.936- \\
1.743)\end{array}$ & 0.122 & \\
\hline & & TT & 13 & 21 & $\begin{array}{l}0.652(0.321- \\
1.321)\end{array}$ & 0.235 & $\begin{array}{l}0.634(0.300- \\
1.339)\end{array}$ & 0.232 & \\
\hline & Dominant & $\mathrm{CC}$ & 362 & 381 & 1 & & 1 & & \\
\hline & & $\mathrm{CT}+\mathrm{TT}$ & 142 & 124 & $\begin{array}{l}1.205(0.910- \\
1.596)\end{array}$ & 0.192 & $\begin{array}{l}1.169(0.871- \\
1.570)\end{array}$ & 0.297 & \\
\hline & Recessive & $\mathrm{CC}+\mathrm{CT}$ & 491 & 484 & 1 & & 1 & & \\
\hline & & TT & 13 & 21 & $\begin{array}{l}0.610(0.302- \\
1.233)\end{array}$ & 0.168 & $\begin{array}{l}0.599(0.285- \\
1.260)\end{array}$ & 0.177 & \\
\hline & Overdominance & $\mathrm{CC}+\mathrm{TT}$ & 375 & 402 & 1 & & 1 & & \\
\hline & & CT & 129 & 103 & $\begin{array}{l}1.343(1.000- \\
1.803)\end{array}$ & 0.050 & $\begin{array}{l}1.360(1.009- \\
1.832)\end{array}$ & 0.043 & \\
\hline
\end{tabular}

${ }^{c} P$ Value of Hardy-Weinberg Equilibrium Test in Controlled Population

Table 3. Stratified analysis of eight SNPs and genetic susceptibility to breast cancer 


\begin{tabular}{|c|c|c|c|c|c|c|c|c|}
\hline & \multicolumn{2}{|c|}{ rs9656964(GC+GG/CC) } & \multicolumn{2}{|c|}{ rs785003(CT+TT/CC) } & \multicolumn{2}{|c|}{ rs117117537(GT+GG/TT) } & \multicolumn{2}{|c|}{ rs1551514(GA+AA/GG) } \\
\hline & OR $(95 \% \mathrm{Cl})^{\mathrm{a}}$ & $P^{a}$ & OR $(95 \% \mathrm{Cl})^{\mathrm{a}}$ & $P^{a}$ & OR $(95 \% \mathrm{Cl})^{\mathrm{a}}$ & $P^{a}$ & OR $(95 \% \mathrm{Cl})^{\mathrm{a}}$ & $P^{a}$ \\
\hline \multicolumn{9}{|c|}{$\begin{array}{l}\text { Age } \\
\text { (year) }\end{array}$} \\
\hline$<50$ & $\begin{array}{l}1.157(0.799- \\
1.677)\end{array}$ & 0.440 & $\begin{array}{l}1.072(0.659- \\
1.745)\end{array}$ & 0.778 & $\begin{array}{l}0.987(0.614- \\
1.587)\end{array}$ & 0.956 & $\begin{array}{l}0.963(0.665- \\
1.396)\end{array}$ & 0.843 \\
\hline$\geq 50$ & $\begin{array}{l}1.119(0.711- \\
1.760)\end{array}$ & 0.627 & $\begin{array}{l}1.505(0.819- \\
2.768)\end{array}$ & 0.188 & $\begin{array}{l}1.584(0.896- \\
2.802)\end{array}$ & 0.114 & $\begin{array}{l}0.699(0.443- \\
1.103)\end{array}$ & 0.124 \\
\hline \multicolumn{9}{|c|}{ Menarche age (year) } \\
\hline$<14$ & $\begin{array}{l}1.430(0.900- \\
2.272)\end{array}$ & 0.130 & $\begin{array}{l}0.932(0.510- \\
1.705)\end{array}$ & 0.932 & $\begin{array}{l}1.505(0.847- \\
2.674)\end{array}$ & 0.163 & $\begin{array}{l}0.947(0.603- \\
1.488)\end{array}$ & 0.813 \\
\hline$\geq 14$ & $\begin{array}{l}0.974(0.680- \\
1.395)\end{array}$ & 0.885 & $\begin{array}{l}1.511(0.925- \\
2.468)\end{array}$ & 0.100 & $\begin{array}{l}1.024(0.647- \\
1.622)\end{array}$ & 0.920 & $\begin{array}{l}0.859(0.596- \\
1.238)\end{array}$ & 0.416 \\
\hline \multicolumn{9}{|c|}{ Menopause age (year) } \\
\hline$<50$ & $\begin{array}{l}1.227(0.650- \\
2.316)\end{array}$ & 0.527 & $\begin{array}{l}0.924(0.378- \\
2.261)\end{array}$ & 0.862 & $\begin{array}{l}0.974(0.447- \\
2.124)\end{array}$ & 0.948 & $\begin{array}{l}0.759(0.411- \\
1.401)\end{array}$ & 0.378 \\
\hline$\geq 50$ & $\begin{array}{l}1.431(0.750- \\
2.728)\end{array}$ & 0.277 & $\begin{array}{l}2.093(0.864- \\
5.068)\end{array}$ & 0.102 & $\begin{array}{l}2.413(1.057- \\
5.508)\end{array}$ & 0.036 & $\begin{array}{l}0.701(0.369- \\
1.329)\end{array}$ & 0.276 \\
\hline \multicolumn{9}{|c|}{ Menopausal status } \\
\hline No & $\begin{array}{l}1.072(0.737- \\
1.561)\end{array}$ & 0.715 & $\begin{array}{l}1.145(0.708- \\
1.853)\end{array}$ & 0.581 & $\begin{array}{l}1.032(0.636- \\
1.675)\end{array}$ & 0.897 & $\begin{array}{l}1.012(0.690- \\
1.484)\end{array}$ & 0.952 \\
\hline Yes & $\begin{array}{l}1.337(0.857- \\
2.085)\end{array}$ & 0.201 & $\begin{array}{l}1.351(0.734- \\
2.488)\end{array}$ & 0.334 & $\begin{array}{l}1.475(0.850- \\
2.558)\end{array}$ & 0.167 & $\begin{array}{l}0.713(0.462- \\
1.099)\end{array}$ & 0.125 \\
\hline \multicolumn{9}{|c|}{ Number of pregnancies } \\
\hline$<2$ & $\begin{array}{l}1.376(0.648- \\
2.925)\end{array}$ & 0.406 & $\begin{array}{l}1.639(0.674- \\
3.988)\end{array}$ & 0.276 & $\begin{array}{l}0.432(0.131- \\
1.428)\end{array}$ & 0.169 & $\begin{array}{l}0.643(0.311- \\
1.329)\end{array}$ & 0.233 \\
\hline$\geq 2$ & $\begin{array}{l}1.166(0.873- \\
1.557)\end{array}$ & 0.298 & $\begin{array}{l}1.145(0.775- \\
1.693)\end{array}$ & 0.495 & $\begin{array}{l}1.303(0.904- \\
1.878)\end{array}$ & 0.157 & $\begin{array}{l}0.940(0.704- \\
1.256)\end{array}$ & 0.676 \\
\hline \multicolumn{9}{|c|}{ Number of abortions } \\
\hline$<2$ & $\begin{array}{l}1.196(0.860- \\
1.664)\end{array}$ & 0.288 & $\begin{array}{l}1.392(0.893- \\
2.169)\end{array}$ & 0.144 & $\begin{array}{l}1.058(0.686- \\
1.632)\end{array}$ & 0.798 & $\begin{array}{l}0.854(0.614- \\
1.188)\end{array}$ & 0.350 \\
\hline$\geq 2$ & $\begin{array}{l}1.115(0.675- \\
1.842)\end{array}$ & 0.671 & $\begin{array}{l}1.092(0.564- \\
2.114)\end{array}$ & 0.795 & $\begin{array}{l}1.443(0.777- \\
2.678)\end{array}$ & 0.246 & $\begin{array}{l}0.940(0.564- \\
1.566)\end{array}$ & 0.812 \\
\hline \multicolumn{9}{|c|}{ Breastfeeding history } \\
\hline No & $\begin{array}{l}1.051(0.554- \\
1.992)\end{array}$ & 0.879 & $\begin{array}{l}2.764(0.977- \\
7.817)\end{array}$ & 0.055 & $\begin{array}{l}0.582(0.248- \\
1.366)\end{array}$ & 0.214 & $\begin{array}{l}1.410(0.760- \\
2.613)\end{array}$ & 0.276 \\
\hline Yes & $\begin{array}{l}1.179(0.860- \\
1.616)\end{array}$ & 0.306 & $\begin{array}{l}1.087(0.721- \\
1.637)\end{array}$ & 0.691 & $\begin{array}{l}1.427(0.956- \\
2.131)\end{array}$ & 0.082 & $\begin{array}{l}0.762(0.553- \\
1.052)\end{array}$ & 0.098 \\
\hline \multicolumn{9}{|c|}{ Family history } \\
\hline No & $\begin{array}{l}1.181(0.883- \\
1.580)\end{array}$ & 0.261 & $\begin{array}{l}1.216(0.829- \\
1.795)\end{array}$ & 0.317 & $\begin{array}{l}1.161(0.801- \\
1.682)\end{array}$ & 0.431 & $\begin{array}{l}0.845(0.631- \\
1.132)\end{array}$ & 0.259 \\
\hline \multirow[t]{3}{*}{ Yes } & $\begin{array}{l}0.861(0.249- \\
2.974)\end{array}$ & 0.813 & $\begin{array}{l}2.701(0.272- \\
26.803)\end{array}$ & 0.396 & $\begin{array}{l}2.070(0.379- \\
11.291)\end{array}$ & 0.401 & $\begin{array}{l}2.198(0.631- \\
7.653\end{array}$ & 0.216 \\
\hline & \multicolumn{2}{|c|}{ rs7823297(TC+TT/CC) } & \multicolumn{2}{|c|}{ rs17762938(TC+CC/TT) } & \multicolumn{2}{|c|}{ rs1551513(TC+CC/TT) } & \multicolumn{2}{|c|}{ rs4473999(CT+TT/CC) } \\
\hline & OR $(95 \% \mathrm{Cl})^{\mathrm{a}}$ & $P^{a}$ & OR $(95 \% \mathrm{Cl})^{\mathrm{a}}$ & $P^{a}$ & OR $(95 \% \mathrm{Cl})^{\mathrm{a}}$ & $P^{a}$ & OR $(95 \% \mathrm{Cl})^{\mathrm{a}}$ & $P^{a}$ \\
\hline
\end{tabular}




\begin{tabular}{|c|c|c|c|c|c|c|c|c|}
\hline$<50$ & $\begin{array}{l}1.157(0.799- \\
1.677)\end{array}$ & 0.440 & $\begin{array}{l}1.157(0.799- \\
1.677)\end{array}$ & 0.440 & $\begin{array}{l}1.198(0.826- \\
1.737)\end{array}$ & 0.341 & $\begin{array}{l}1.124(0.756- \\
1.672)\end{array}$ & 0.563 \\
\hline$\geq 50$ & $\begin{array}{l}1.103(0.702- \\
1.734)\end{array}$ & 0.670 & $\begin{array}{l}1.119(0.711- \\
1.760)\end{array}$ & 0.627 & $\begin{array}{l}\text { 1.155(0.733- } \\
1.819)\end{array}$ & 0.534 & $\begin{array}{l}1.301(0.828- \\
2.043)\end{array}$ & 0.254 \\
\hline \multicolumn{9}{|c|}{ Menarche age (year) } \\
\hline$<14$ & $\begin{array}{l}1.405(0.886- \\
2.229)\end{array}$ & 0.149 & $\begin{array}{l}1.430(0.900- \\
2.272)\end{array}$ & 0.130 & $\begin{array}{l}1.449(0.910- \\
2.309)\end{array}$ & 0.118 & $\begin{array}{l}1.538(0.925- \\
2.560)\end{array}$ & 0.097 \\
\hline$\geq 14$ & $\begin{array}{l}0.974(0.680- \\
1.395)\end{array}$ & 0.885 & $\begin{array}{l}0.974(0.680- \\
1.395)\end{array}$ & 0.885 & $\begin{array}{l}1.019(0.711- \\
1.459)\end{array}$ & 0.920 & $\begin{array}{l}0.997(0.692- \\
1.435)\end{array}$ & 0.986 \\
\hline \multicolumn{9}{|c|}{ Menopause age (year) } \\
\hline$<50$ & $\begin{array}{l}1.227(0.650- \\
2.316)\end{array}$ & 0.527 & $\begin{array}{l}1.227(0.650- \\
2.316)\end{array}$ & 0.527 & $\begin{array}{l}1.235(0.654- \\
2.333)\end{array}$ & 0.515 & $\begin{array}{l}0.948(0.511- \\
1.757)\end{array}$ & 0.864 \\
\hline$\geq 50$ & $\begin{array}{l}1.394(0.733- \\
2.652)\end{array}$ & 0.311 & $\begin{array}{l}1.431(0.750- \\
2.728)\end{array}$ & 0.277 & $\begin{array}{l}1.459(0.765- \\
2.783)\end{array}$ & 0.252 & $\begin{array}{l}2.137(1.065- \\
4.286)\end{array}$ & 0.032 \\
\hline \multicolumn{9}{|c|}{ Menopausal status } \\
\hline No & $\begin{array}{l}1.072(0.737- \\
1.561)\end{array}$ & 0.715 & $\begin{array}{l}1.072(0.737- \\
1.561)\end{array}$ & 0.715 & $\begin{array}{l}1.104(0.757- \\
1.608)\end{array}$ & 0.608 & $\begin{array}{l}1.109(0.745- \\
1.651)\end{array}$ & 0.612 \\
\hline Yes & $\begin{array}{l}1.315(0.844- \\
2.050)\end{array}$ & 0.227 & $\begin{array}{l}1.337(0.857- \\
2.085)\end{array}$ & 0.201 & $\begin{array}{l}1.374(0.880- \\
2.144)\end{array}$ & 0.162 & $\begin{array}{l}1.332(0.850- \\
2.089)\end{array}$ & 0.211 \\
\hline \multicolumn{9}{|c|}{ Number of pregnancies } \\
\hline$<2$ & $\begin{array}{l}1.376(0.648- \\
2.925)\end{array}$ & 0.406 & $\begin{array}{l}1.376(0.648- \\
2.925)\end{array}$ & 0.406 & $\begin{array}{l}1.376(0.648- \\
2.925)\end{array}$ & 0.406 & $\begin{array}{l}0.936(0.406- \\
2.156)\end{array}$ & 0.876 \\
\hline$\geq 2$ & $\begin{array}{l}1.156(0.866- \\
1.544)\end{array}$ & 0.324 & $\begin{array}{l}1.166(0.873- \\
1.557)\end{array}$ & 0.298 & $\begin{array}{l}1.216(0.909- \\
1.625)\end{array}$ & 0.187 & $\begin{array}{l}1.335(0.982- \\
1.816)\end{array}$ & 0.066 \\
\hline \multicolumn{9}{|c|}{ Number of abortions } \\
\hline$<2$ & $\begin{array}{l}1.196(0.860- \\
1.664)\end{array}$ & 0.288 & $\begin{array}{l}1.196(0.860- \\
1.664)\end{array}$ & 0.288 & $\begin{array}{l}1.261(0.906- \\
1.756)\end{array}$ & 0.169 & $\begin{array}{l}1.510(1.045- \\
2.181)\end{array}$ & 0.028 \\
\hline$\geq 2$ & $\begin{array}{l}1.099(0.666- \\
1.815)\end{array}$ & 0.712 & $\begin{array}{l}1.115(0.675- \\
1.842)\end{array}$ & 0.671 & $\begin{array}{l}1.096(0.662- \\
1.814)\end{array}$ & 0.722 & $\begin{array}{l}0.835(0.515- \\
1.353)\end{array}$ & 0.464 \\
\hline \multicolumn{9}{|c|}{ Breastfeeding history } \\
\hline No & $\begin{array}{l}1.051(0.554- \\
1.992)\end{array}$ & 0.879 & $\begin{array}{l}1.051(0.554- \\
1.992)\end{array}$ & 0.879 & $\begin{array}{l}1.100(0.578- \\
2.092)\end{array}$ & 0.772 & $\begin{array}{l}0.942(0.408- \\
2.177)\end{array}$ & 0.942 \\
\hline Yes & $\begin{array}{l}1.171(0.854- \\
1.605)\end{array}$ & 0.326 & $\begin{array}{l}1.179(0.860- \\
1.616)\end{array}$ & 0.306 & $\begin{array}{l}1.206(0.879- \\
1.645)\end{array}$ & 0.245 & $\begin{array}{l}1.317(0.925- \\
1.875)\end{array}$ & 0.127 \\
\hline \multicolumn{9}{|c|}{ Family history } \\
\hline No & $\begin{array}{l}1.175(0.879- \\
1.571)\end{array}$ & 0.277 & $\begin{array}{l}1.181(0.883- \\
1.580)\end{array}$ & 0.261 & $\begin{array}{l}1.204(0.899- \\
1.612)\end{array}$ & 0.213 & $\begin{array}{l}1.252(0.910- \\
1.724)\end{array}$ & 0.168 \\
\hline Yes & $\begin{array}{l}0.861(0.249- \\
2.974)\end{array}$ & 0.813 & $\begin{array}{l}0.861(0.249- \\
2.974)\end{array}$ & 0.813 & $\begin{array}{l}1.036(0.310- \\
3.464)\end{array}$ & 0.954 & $\begin{array}{l}0.493(0.113- \\
2.147)\end{array}$ & 0.346 \\
\hline
\end{tabular}

${ }^{a}$ Logistic regression analysis adjusted for age, menarche age, menopausal status, number of pregnancies, number of abortions, history of breastfeeding, and post-family $P$ values.

Table 4. Haplotype analysis of PCAT1 SNPs (3\%) 


\begin{tabular}{|c|c|c|c|c|c|c|}
\hline Gene & Haplotype $^{a}$ & Cases $₫ \% \rrbracket$ & Controls $₫ \% \bigotimes$ & $x^{2}$ & $P$ & $\mathrm{OR}(95 \% \mathrm{Cl})$ \\
\hline \multirow[t]{7}{*}{ PCAT1 } & АТССТССТ & $339.94(33.7)$ & $348.28(34.5)$ & 0.019 & 0.889 & $0.987(0.818-1.190)$ \\
\hline & АТТСТССТ & $65.05(6.5)$ & $62.83(6.2)$ & 0.088 & 0.767 & $1.056(0.737-1.512)$ \\
\hline & GCCGCTCG & $64.75(6.4)$ & $63.97(6.3)$ & 0.027 & 0.870 & $1.030(0.720-1.474)$ \\
\hline & GCCGCTCT & $81.14(8.1)$ & $90.27(8.9)$ & 0.388 & 0.534 & $0.905(0.661-1.239)$ \\
\hline & GTCCTCCT & $275.64(27.3)$ & $294.08(29.1)$ & 0.488 & 0.485 & $0.932(0.766-1.135)$ \\
\hline & GTCCTCTT & $76.69(7.6)$ & $49.83(4.9)$ & 6.574 & 0.010 & $1.614(1.116-2.333)$ \\
\hline & GTTCTCCT & $36.24(3.6)$ & $45.14(4.5)$ & 0.875 & 0.350 & $0.808(0.517-1.264)$ \\
\hline
\end{tabular}

${ }^{a}$ The order of SNP is : rs 1551514, rs 1551513, rs447399, rs9656964, rs17762938, rs7823297, rs785003, rs 117117537

Table 5. Interaction between PCAT1 SNPs and reproductive factors

\begin{tabular}{|c|c|c|c|c|c|c|}
\hline Model & $\begin{array}{l}\text { Average } \\
\text { Accuracy of } \\
\text { Training Set }\end{array}$ & $\begin{array}{l}\text { Average } \\
\text { Accuracy of } \\
\text { Test Set }\end{array}$ & $\begin{array}{l}\text { Ten fold cross } \\
\text { validation } \\
\text { consistency rate }\end{array}$ & $\chi^{2}$ & $P$ & $\mathrm{OR}(95 \% \mathrm{Cl})$ \\
\hline Number of pregnancies & 0.5807 & 0.5649 & $10 / 10$ & 25.950 & $<0.001$ & $\begin{array}{l}1.916(1.490- \\
2.463)\end{array}$ \\
\hline $\begin{array}{l}\text { rs } 4473999 \text { Number of } \\
\text { pregnancies }\end{array}$ & 0.5971 & 0.5519 & $5 / 10$ & 37.260 & $<0.001$ & $\begin{array}{l}2.208 \\
(1.709- \\
2.853)\end{array}$ \\
\hline $\begin{array}{l}\text { rs } 44739990 \text { Number of } \\
\text { pregnancies } 1 \text { Breastfeeding } \\
\text { history }\end{array}$ & 0.6137 & 0.5837 & $10 / 10$ & 50.350 & $<0.001$ & $\begin{array}{l}2.487(1.929- \\
3.206)\end{array}$ \\
\hline
\end{tabular}

\section{Figures}



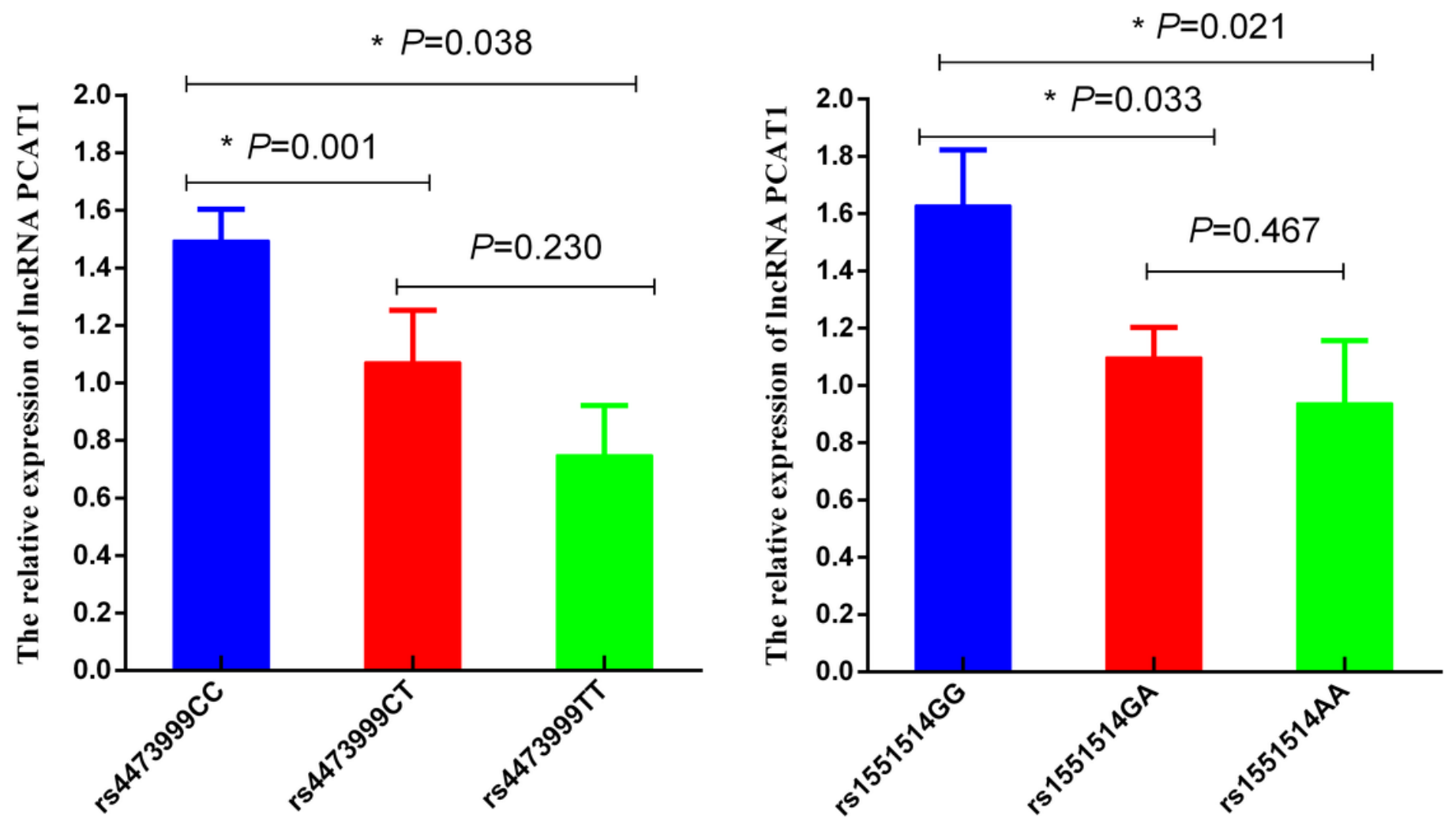

Figure 1

(Relative expression levels of PCAT1 in plasma of three genotypes, SNP rs4473999 (right) and rs1551514 (left)). The result showed that the relative expression of PCAT1 was different between SNP rs1551514 or rs4473999 genotypes, mainly manifested in WT vs MUT $(P=0.021, P=0.038)$ and $W T$ vs heterozygous $(P=0.033, P=0.001)$. 


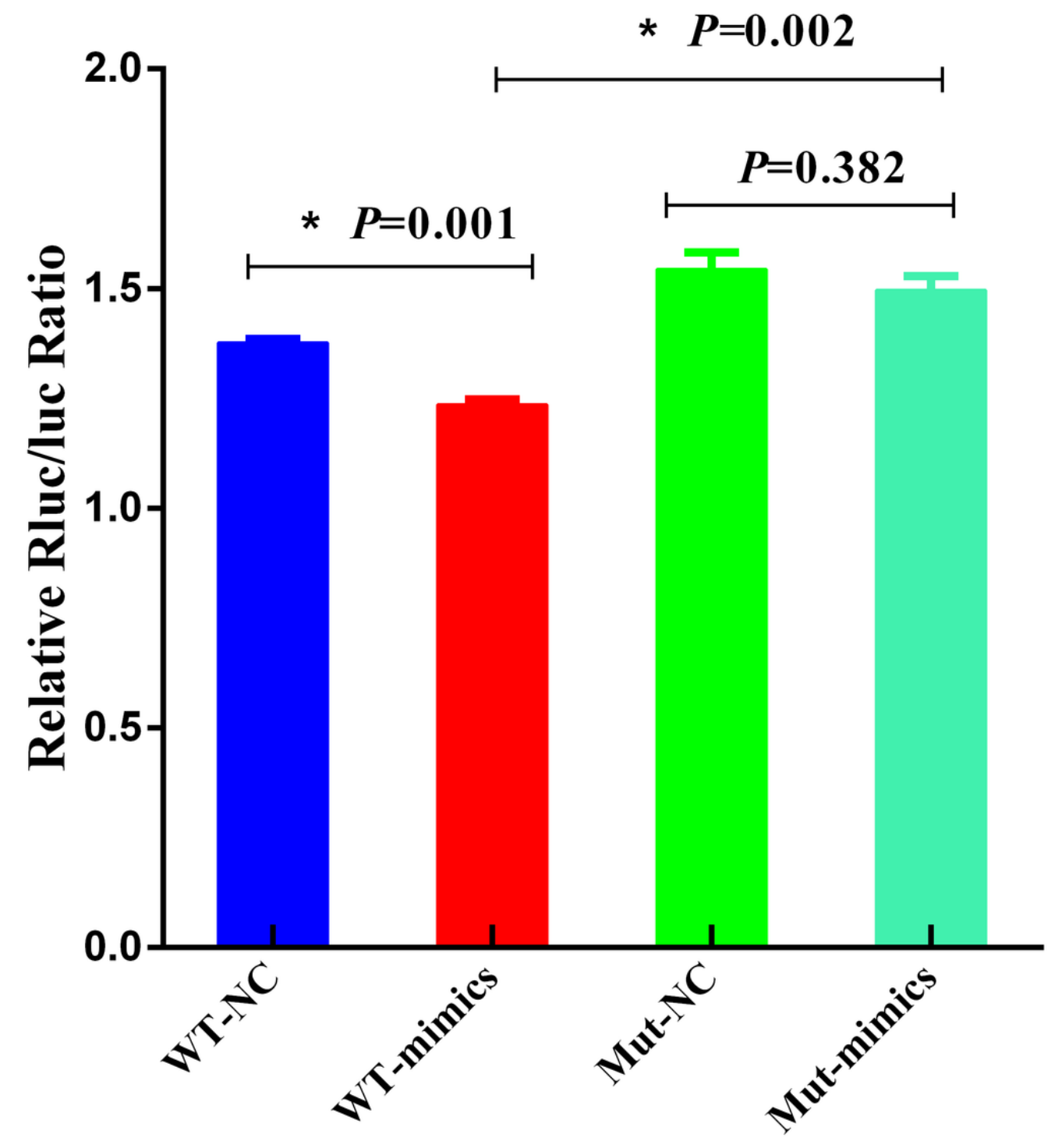

Figure 2

(PCAT1 rs4473999 and miR-149-5p dual luciferase reporter gene results). The results suggested that rs4473999-WT could bind to miR149-5p. 
A
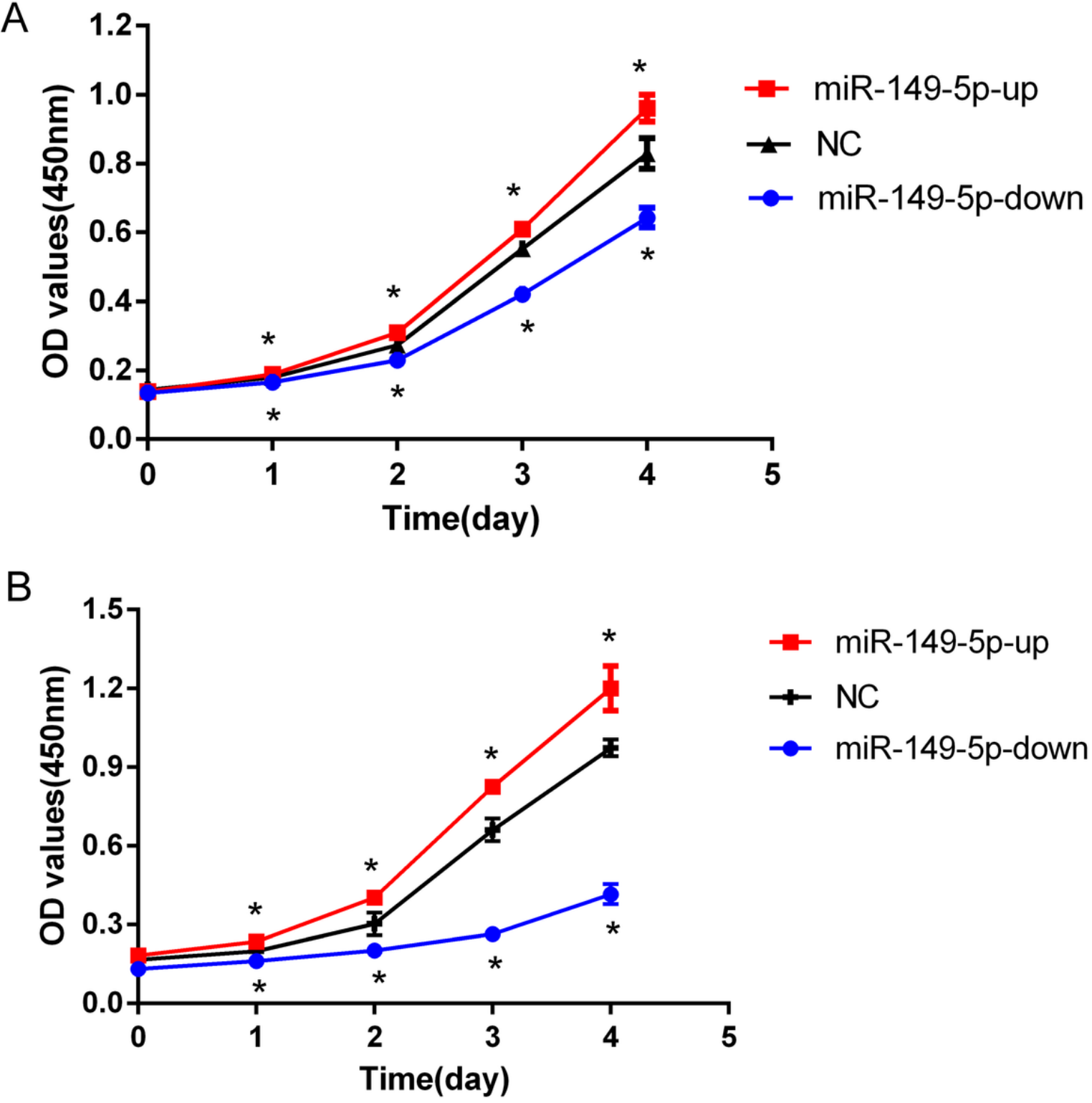

Figure 3

(The effect of miR-149-5p combined with PCAT1 SNP on the proliferation of MDA-MB-231(A) and MCF-7(B) breast cancer cells (0-96h)) The low expression of miR-149-5p may inhibit the proliferation of breast cancer cells; the overexpression of miR-149-5p may promote the proliferation of breast cancer cells. 
A
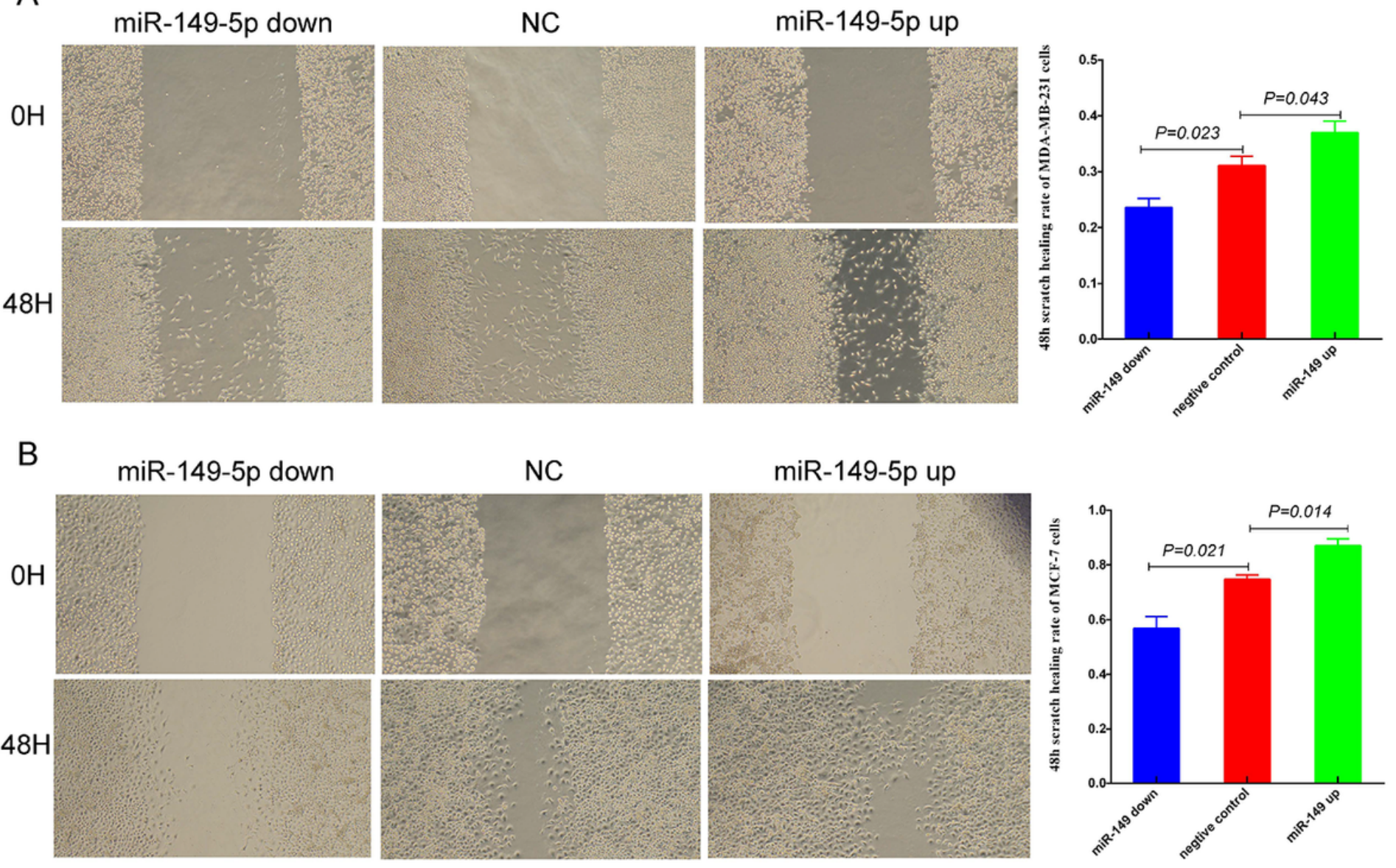

\section{Figure 4}

(Effect of miR-149-5p combined with PCAT1 SNP on the migration ability of MDA-MB-231(A) and MCF-7(B) breast cancer cell). The low expression of miR-149-5p may inhibit the migration of breast cancer cells; the overexpression of miR-149-5p may promote the migration of breast cancer cells. 
A
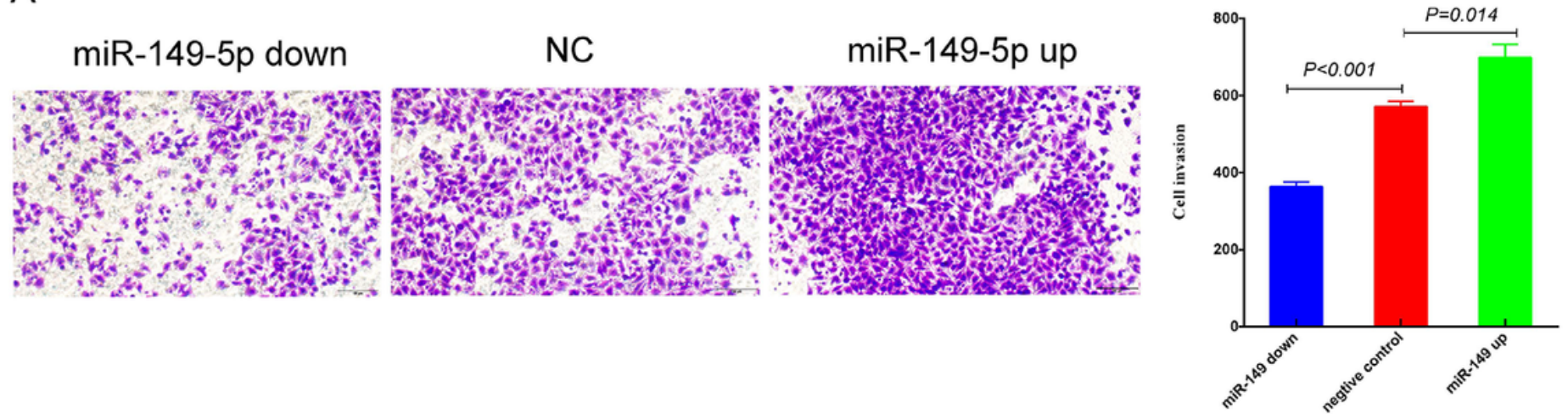

B
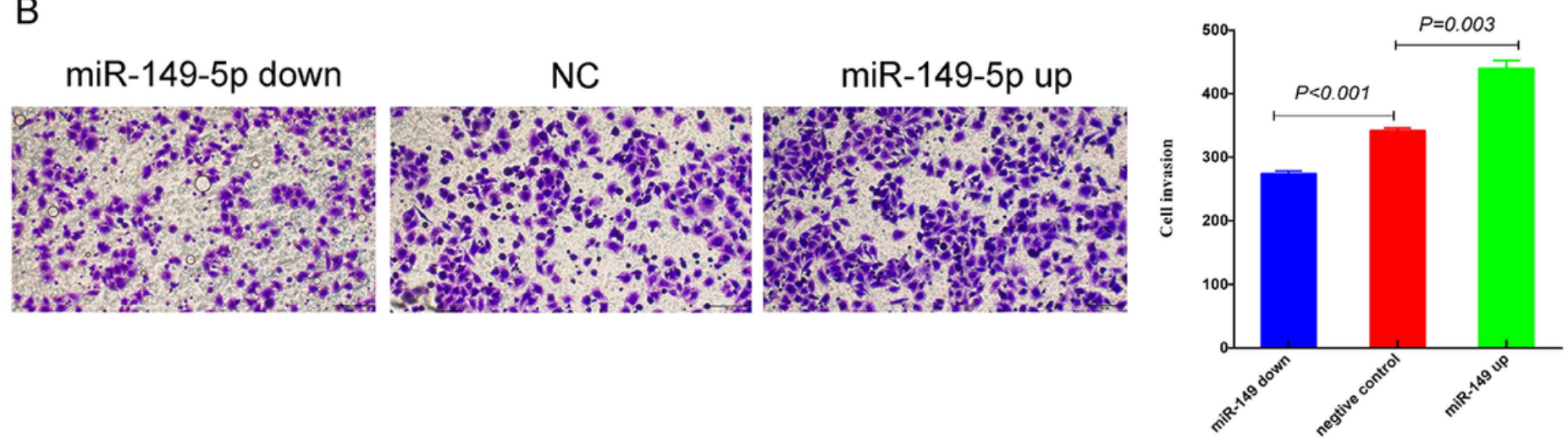

Figure 5

(Effect of miR-149-5p combined with PCAT1 SNP on the invasion ability of MDA-MB-231(A) and MCF-7(B) breast cancer cells). The low expression of miR-149-5p may inhibit the invasion of breast cancer cells; the overexpression of miR-149-5p may promote the invasion of breast cancer cells.

\section{Supplementary Files}

This is a list of supplementary files associated with this preprint. Click to download.

- FigureS1.tif

- Tables1S6.docx 